\title{
The Impact of Climate on Atmospheric Emissions: Constructing an Index of Heating Degrees for 21 OECD Countries from 1960 to $2005^{*}$
}

\author{
DETLEF JAHN \\ Department of Political Science, University of Greifswald, Greifswald, Germany
}

(Manuscript received 29 September 2011, in final form 11 December 2012)

\begin{abstract}
The impact of climate on atmospheric emissions is a highly neglected aspect in research on environmental performance. Cold winters may be a major factor for the increase in heating needs and energy consumption, which may in turn lead to substantial increases in atmospheric emissions, thus contributing to climate change. To measure such an impact, this article develops an index that measures the heating requirements in highly populated regions in 21 Organisation for Economic Co-operation and Development (OECD) countries from 1960 to 2005. Applying this index of heating degree months (HDMs) to atmospheric emissions shows that climate has a significant effect. This is above all true for particular atmospheric emissions that have not been substantially reduced over the last three decades. For atmospheric emissions that have been substantially reduced, climate has no explanatory power, suggesting that other factors such as policies and technological development may explain the reduction. These results remain robust when controlling for various aspects of energy production, economic development, and structural changes.
\end{abstract}

\section{Introduction}

Defining the parameters that contribute to environmental pollution is an important requirement for understanding and combating environmental degradation. Technological, economic, and political aspects are often presented as explanatory variables (Neumayer 2003; Li and Reuveny 2009), with some studies also stressing the importance of changes in production sectors (Jänicke et al. 1989) and others studies combining structural, economic, and political explanations (Jahn 1998; Scruggs 2003). However, this article argues that another aspect has been neglected in environmental studies: the impact of climate and weather conditions. The rationale of considering this aspect is straightforward: countries in cold climates, as well as years with severe winters, require more energy for heating, thus leading to increased atmospheric emissions. Neglecting the regional climate

\footnotetext{
* Supplemental information related to this paper is available at the Journals Online website: http://dx.doi.org/10.1175/ WCAS-D11-00050.s1.

Corresponding author address: Detlef Jahn, Baderstr. 6/7, 17487 Greifswald, Germany.

E-mail:djahn@uni-greifswald.de
}

and weather patterns generates an omitted variable bias, which in turn may lead to false results.

While the term "climate" incorporates elements of precipitation, humidity, and temperature, in order to remain succinct this article focuses exclusively on temperature. Notwithstanding this limitation, it is nevertheless difficult to accurately determine the average temperature in a country in a specific year. Canada presents an excellent example in this regard. Taking the average of all Canadian climate stations misrepresents the relevant average temperature in Canada because of the numerous stations placed in the largely uninhabited north. The relevant temperature should focus more on populated areas where human-initiated emissions are concentrated. Therefore, it is necessary to implement population weighting that considers the population distribution in a given country.

To illustrate the impact of climate on environmental performance, the atmospheric emissions in 21 established Organisation for Economic Co-operation and Development (OECD) countries over a time period from 1960 to 2005 will be analyzed. The countries and time period have been chosen because the 21 established OECD countries are the most highly industrialized democracies, which pollute disproportionally more than their population while simultaneously possessing the capacity to 
reduce pollution by technological and political means. According to the hypothesis of this article, in these countries the impact of climate on environmental pollution should be statistically insignificant because changes in atmospheric emissions are determined by factors other than climate and weather conditions. More specifically, atmospheric emissions successfully reduced in recent decades, such as sulfur oxide $\left(\mathrm{SO}_{\mathrm{x}}\right)$ and carbon monoxide (CO), should not be determined by climate and weather conditions in contrast to emissions less successfully combated, such as nitrous oxide $\left(\mathrm{NO}_{\mathrm{x}}\right)$ and carbon dioxide $\left(\mathrm{CO}_{2}\right)$. The implied causality behind this suggests that the reduction of pollution is initiated by human and political action and therefore decoupled from the impact of climate and weather conditions. If this hypothesis is correct, one may assume that atmospheric emissions where $\mathrm{NO}_{\mathrm{x}}$ and $\mathrm{CO}_{2}$ contribute a substantial part are "caused" to a significant degree by climate and weather conditions.

The article is structured in three parts. In the following section, the major elements of an index of heating degree months (HDMs) are described. In section 3, empirical data for $21 \mathrm{OECD}$ countries over the time period from 1960 to 2005 are reported. Part 4 conducts a statistical analysis in order to estimate the impact of climate and weather conditions on atmospheric emissions along the lines of the above outlined hypothesis.

\section{Toward an index of the heating degrees for 21 OECD countries from 1960 to 2005}

Heating degrees are quantitative indices designed to reflect the energy needed to heat a home or business to a comfortable temperature. These indices are derived from regular temperature observations and the heating requirements at a specific location. ${ }^{1}$ The U.S. Department of Commerce and the European Commission (2007) have developed highly sophisticated indices of heating degree days (HDDs) with the United States having the most developed index available. The U.S. Department of Commerce publishes the HDDs since 1930s on an annual basis. [Note that HDD and cooling degree day (CDD) data for the United States are actually available from 1885 to the present; see http://www7. ncdc.noaa.gov/CDO/CDODivisionalSelect.jsp.] The major reason for this tradition is to predict the demand

\footnotetext{
${ }^{1}$ In practice heating degrees may vary over time and between countries according to the standard of buildings. However, this aspect could not been taken into account because no information is available for a systematic analysis. For the methodological consequences, see also footnote 2 .
}

for heating fuel. HDDs are defined relative to a base temperature-the outside temperature below which a building needs heating. The most appropriate base temperature for any particular building depends on the temperature that the building is heated to and the nature of the building (including the heat-generating occupants and equipment within it). However, for historical reasons, HDDs are often calculated with base temperatures of $65^{\circ} \mathrm{F}\left(18.3^{\circ} \mathrm{C}\right)$ (U.S. Department of Commerce) or $15^{\circ} \mathrm{C}$ (European Commission). In this article a base temperature of $15^{\circ} \mathrm{C}$ has been used. ${ }^{2}$

To obtain a single value for a state, or the whole of the United States, in this article the HDDs are weighted by the population living under specific climatic conditions. The United States was divided into nine census regions as defined by the Census Bureau. Their weights were obtained by the population of the states. The average annual number of HDDs for the United States in 2008 was 4330 . That means that over the year there is a heating need of almost $12^{\circ} \mathrm{F}\left(6.7^{\circ} \mathrm{C}\right)$ every day. Of course, heating requirements are higher in winter than in summer. Unfortunately, such a detailed measure over an extended time period is only available for the United States. Nevertheless, there are some efforts to construct similar measures for various countries or regions.

The European Commission (2007) introduced a similar index that reaches back to 1980 . Daily temperature was measured at around 300 climate stations in all European Union (EU) member states. For each of these stations, population figures were added from the Nomenclature of Territorial Units for Statistics (NUTS). Regions and climate stations were unevenly distributed. There were 40 stations for Germany, 22 for France, and 18 for Spain. Estonia had only one. The HDDs are summarized for each country and for the whole EU. According to the European Commission, 3386 HDDs was the

\footnotetext{
${ }^{2}$ The base temperature $65^{\circ} \mathrm{F}$ or $15^{\circ} \mathrm{C}$ is rather arbitrary. However, $15^{\circ} \mathrm{C}$ is grounded in the research of thermal comfort models [Fanger 1973; for a recent overview see Orosa (2009)]. Research on thermoregulation and heat balance theory describes thermal comfort as the discrepancy between actual heat flow from the body in a given thermal environment and the heat flow required for optimal comfort for a given activity. This is dependent on air temperature, average temperature radiant, air velocity, and the absolute humidity of the air. The minimal accepted value is $15^{\circ} \mathrm{C}$ (see also ASHRAE 2004). However, the HDM index is relatively robust no matter which base temperature is used. For instance, the HDM index correlates highly (Pearson's $r=0.985$ ) with $65^{\circ} \mathrm{F}$ and $15^{\circ} \mathrm{C}$. Since all countries included in this study are highly industrialized and have similar housing standards, the base temperature of $15^{\circ} \mathrm{C}$ is used for all 21 countries over the whole period. Although one may argue that there are differences between countries and periods, quantifying those differences is not possible within the framework of this study.
} 
long-term average from 1980 to 2004 in the EU. The different base temperatures and temperature scales for the HDDs in the United States and the EU make it difficult to compare the HDDs in the United States and Europe. However, the focus of this article is on 21 OECD countries, and therefore it is necessary to consider an index that is also applicable to the remaining OECD countries such as Australia, Canada, Japan, Norway, New Zealand, and Switzerland.

Because it is not possible to obtain HDDs for all 21 OECD countries for an extended time period from existing HDD databases, the data collected for this study rely on monthly temperature data, shifting from HDDs to HDMs. ${ }^{3}$ To construct the index of HDMs, three aspects have to been taken into account: 1) identifying temperature differences in each country, 2) locating climate stations with an extended record of monthly data reporting, and 3) obtaining time-variant information about the number of people living in each climate zone of a country.

\section{a. Identifying national temperature differences}

To identify a representative range of temperature differences in each country, climatic maps referring to Wladimir Köppen's climate regions has been used (Köppen 1900, 1918; Köppen and Geiger 1936). Among all other classification systems, Köppen's prevailed (Sanderson 1999; Essenwanger and Landsberg 2001) and his system has been used recently for estimating global warming and greenhouse scenarios (Barnett 2005). In this context, it has been concluded that in comparison to other typologies, "the Köppen classification is easier to apply and is still a useful tool for estimating the ability of climate models to reproduce the present climate as well as indicate the impact of climate changes on the biosphere" (Lohmann et al. 1993). However, over the years, the empirical classification has been further developed through introducing a growing number of climate stations (Kottek et al. 2006). The classification of climate zones in this study relies on the newest comprehensive system developed by Peel et al. (2007).

In this study, the most relevant climate zones are where a substantial proportion of the population of a country is living. We use the full three-order classification system for identifying country-specific climate zones.

\footnotetext{
${ }^{3}$ HDMs are obviously less precise than HDDs and leads to fewer heating degrees. However, as shown in footnote 8, the HDM index constructed in this article correlates strongly with the HDD index for the countries and time period where both indices are available.
}

However, in the case of large climate zones with several highly populated areas, more than one climate station has been included in the study. Further details are given in the description of the regional maps in the last section of this part of the article.

\section{b. Identifying climate stations}

Once the major climate zones with significant populations were specified, monthly temperature data from 1960 to 2005 in the 21 OECD countries were collected. To collect the temperature data, various data sources such as the Computational and Information Systems Laboratory (CISL), Deutscher Wetterdienst (www.dwd. de), EDI (2009), Meteored (http://clima.tiempo.com/), and the National Aeronautics and Space Administration (NASA; http://data.giss.nasa.gov/csci/stations; data were used for 2008 and 2009) have been used. [Note that the data for this study are above all from the Research Data Archive (RDA), which is maintained by CISL at the National Center for Atmospheric Research (NCAR). The original data are available from the RDA (http:// dss.ucar.edu) in dataset number ds570.0.] From these data sources, 91 climate stations have been selected that have a relatively uninterrupted monthly report of mean temperature and that were representative for a national region with long-term population data. ${ }^{4}$

\section{c. Regional population data}

The population data were mainly taken from Lahmeyer (2006) with the exception of Australia, Japan, and the United States-for which more detailed annual national data from the national statistical bureaus were available. Lahmeyer reports regional population data from national censuses and official estimates from subnational administrative districts. \{For Australia, see Australian Historical Population Statistics, 2008 (http://www.abs. gov.au/AUSSTATS/abs@.nsf/DetailsPage/3105.0.65. 0012008? OpenDocument; downloaded June 2012). For Japan, see Historical Data of Japan [2-5 Population by Prefecture and Sex (1884-2009)] (http://www.stat.go.jp/ english/data/chouki/02.htm; downloaded June 2012). For the United States, see United States Census Bureau (Table 14. State Population-Rank, Percent Change, and Population Density) (http://www.census.gov/compendia/ statab/2012/tables/12s0014.pdf, downloaded June 2012).

Table A1 in the appendix shows all the climate stations used in this study for each country and the regions that have been aligned to these stations. In some countries,

\footnotetext{
${ }^{4}$ For some years, multiple imputations were used to complete the dataset by using climate stations from the same region and with high correlation.
} 


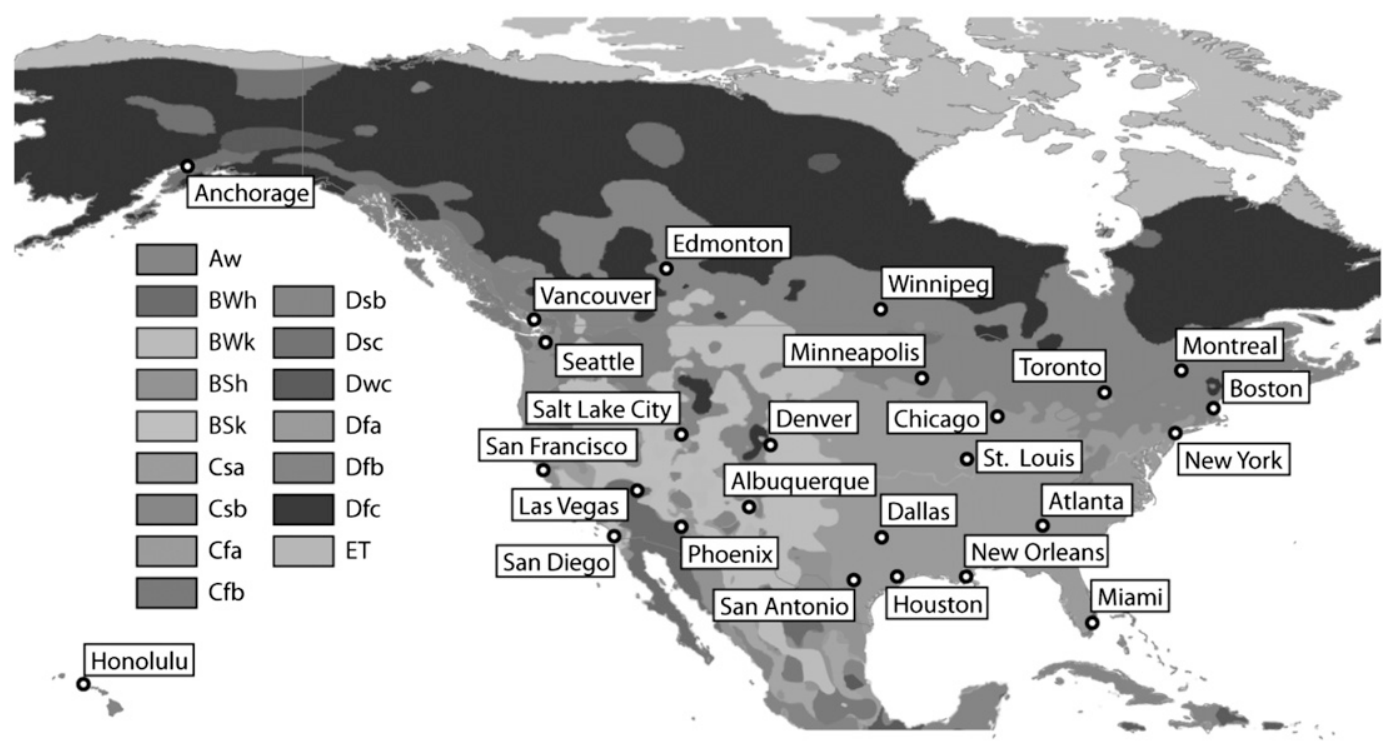

FIG. 1. Climate zones and selected climate stations in Canada and the United States. Explanations: Aw = tropical: savannah; $\mathrm{BWh}=$ arid: hot desert; $\mathrm{BWk}=$ arid: cold desert; $\mathrm{BSh}=$ arid: hot steppe; $\mathrm{BSk}=$ arid: cold steppe; Csa = temperate: dry and hot summer; $\mathrm{Csb}=$ temperate: dry and warm summer; $\mathrm{Cfa}=$ temperate: without dry season and hot summer; $\mathrm{Cfb}=$ temperate: without dry season and warm summer; Dsb = cold: dry and warm summer; Dsc $=$ cold: dry and cold summer; Dwc = cold: dry winter and cold summer; Dfa = cold: without dry season and hot summer; Dfb = cold: without dry season and warm summer; Dfc = cold: without dry season and cold summer; ET = polar: tundra. (For color map, see Fig. S1 in the supplementary material. Supplementary material is available online at http://dx.doi.org/10.1175/WCAS-D-11-00050.s1.) Source: Map from Peel et al. (2007); cities for the selected climate stations are added to the map by the author. (This figure is also available in color online at http:// comparativepolitics.uni-greifswald.de.)

information was very detailed while in others only a very rough indicator could be obtained. To be consistent, it was necessary to use relatively complete temperature data for the same climate stations from 1960 to 2005, as well as a relatively complete dataset for the population in identical regions over the same time period. ${ }^{5}$ Nevertheless, climate stations often stopped reporting and regions were restructured. Therefore, some further details about the operationalization for each of the countries included in the study are presented in Table A1.

The United States is the most climactically complex country (see also Fig. 1) with a large territory, thus making it necessary to include 22 climate stations for the United States alone (see Table A 2 in the appendix). For each climate station, specific states were aligned. In California, two climate stations have been used: San Francisco for North California and San Diego for South California. Texas is the largest state in the contiguous

\footnotetext{
${ }^{5}$ Regional population data are dependent on a census or official estimations. These data points were not available annually. Therefore data points were interpolated from one observation to the other.
}

United Sates and is split into three areas but just one climate zone. Since population is concentrated in Houston, Dallas, and San Antonio, climate stations from these three cities were included, where Houston and Dallas are weighted equal with 1 and San Antonio with 0.5 . Other cities were each taken as representative of several states; these include Atlanta, New York, Boston, Chicago, Salt Lake City, Minneapolis, and St. Louis.

To illustrate the location of selected climate stations within the specific climatic zones, maps with the climate zones and the name of the city where the climate station is located are shown in Figs 1-4. Figure 1 shows the climate zones and the location of the climate stations for the United States and Canada.

Figure 1 demonstrates the considerable variety of climate zones in the United States-reaching from tropical zones in Hawaii to arid zones in California and Texas, temperate zones along the Pacific coast and in the southeast, cold zones with hot or warm summers in the northeast, and cold zones with dry and cold summers in Alaska. In Canada, all climate stations are in cold climate zones (Dfa) with the exception of Vancouver, which is in the temperate climate zone. However, because 


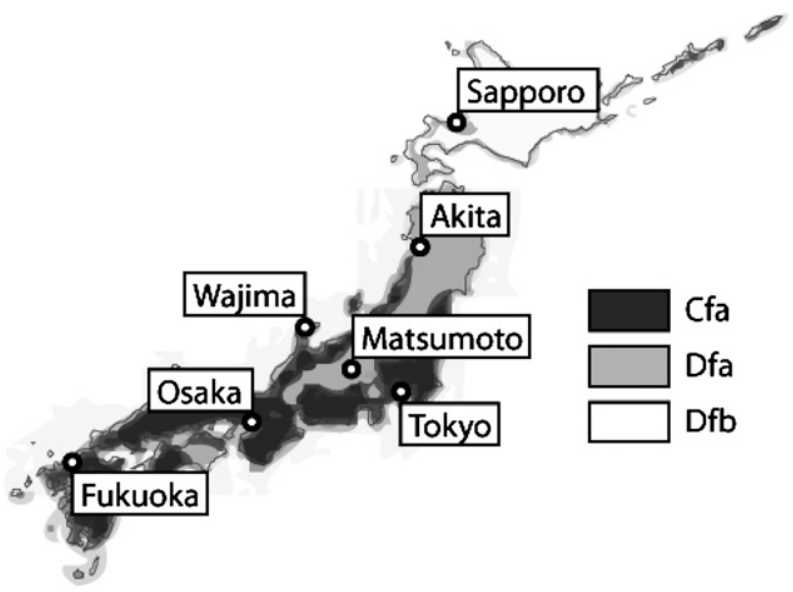

FIG. 2. Climate zones and selected climate stations in Japan. Explanations: $\mathrm{Cfa}=$ temperate: without dry season and hot summer; Dfa = cold: without dry season and hot summer; Dfb $=$ cold: without dry season and warm summer. (For color map, see Fig. S2 in the supplementary material.) Source: Map from Peel et al. (2007); cities for the selected climate stations are added to the map by the author. (This figure is also available in color online at http:// comparativepolitics.uni-greifswald.de.)

considerable variation of temperature exists in the cold climate zone of Canada, four climate stations within the same climate zone are included. ${ }^{6}$

Japan is another challenging case for constructing a climate index because it stretches more than $3000 \mathrm{~km}$ from north to south. Japan is divided into three principal climatic zones with substantial temperature variations within each. Therefore seven climate stations have been used to calculate Japan's HDMs.

Europe has several distinct climate zones and most countries have varied weather conditions within their borders. In particular, the Nordic countries (Norway, Sweden, and Finland) and Italy in southern Europe stretch from north to south for a considerable distance, which made it necessary to collect data from various climate stations.

Spain is the European country with the most climate zones. The weather conditions vary from cool and wet areas on the Atlantic coast and hot and dry zones in the south, to the moderate zone of the highland surrounding Madrid. Catalonia and the Balearic Islands also have a distinct climate, as well as the Canary Islands. In addition, there are also substantial differences within climate zones that led to the inclusion of additional climate stations.

\footnotetext{
${ }^{6}$ For instance, in the year 2000 , the average winter temperature (December-February) was $-10.7^{\circ} \mathrm{C}$ for Edmonton, $-16.07^{\circ} \mathrm{C}$ for Winnipeg, $-5.37^{\circ} \mathrm{C}$ for Toronto, and $-8.7^{\circ} \mathrm{C}$ for Montreal.
}

The alpine character of Switzerland-although a relatively small country-results in seven distinct climate zones. Except for the high mountain area, which is uninhabited and therefore not relevant for the calculation of this index, six climate zones have to be taken into consideration. [The Swiss data were collected from national source: (http://www.meteoschweiz.admin.ch/web/ de/klima/klima_heute/homogene_reihen.html, accessed April 2009)].The respective cantons were aligned with the six selected climate stations as documented in Table A1.

Germany, the United Kingdom, and France have a low number of climate zones. However, because of their size, climate stations from different areas have been selected.

In New Zealand, frequent regional reforms limited the selection of population regions to simply the North Island and the South Island, thus limiting the climate stations accordingly.

Although Australia has a sizable territory, people live in a few densely populated urban conglomerates mainly on the temperate coast. Townsville represents the Northern Territory with a tropical climate, which is, however, much less populated than the southern and the southeastern parts of Australia. After the description of the specific aspects of selecting climate stations, the following section outlines the technical aspect of the HDM index and shows some empirical data.

\section{An index of heating degree months in 21 OECD countries from 1960 to 2005}

The HDM index is derived from the difference of the base temperature to the actual monthly temperature for each region, weighting it by the regional population in order to obtain the average annual national HDMs. The total index for the HDMs for a country $c$ at year $t$ is

$$
\begin{aligned}
& \operatorname{HDMs}_{c, t} \\
& =\sum_{i}^{n}\left[\sum_{m=1}^{12}\left(15^{\circ} \mathrm{C}-\left\{\begin{array}{lll}
T_{m}, & \text { if } & T_{m}<15^{\circ} \mathrm{C} \\
15^{\circ} \mathrm{C}, & \text { if } & T_{m} \geq 15^{\circ} \mathrm{C}
\end{array}\right) \sum_{i}^{n} \frac{P_{i}}{P_{n}}\right]_{c, t} .\right.
\end{aligned}
$$

In the equation $i$ stands for the $i$ th region of a country $c, m$ are the months reaching from January (1) to December (12). Also, $T_{m}$ is the mean temperature of a respective month where $T<15^{\circ} \mathrm{C}$; when $T>15^{\circ} \mathrm{C}, T$ is set to 15 for that month; $P_{i}$ is the population in the $i$ th region aligned to the climate station that is representative for the region and $P_{n}$ is the total population. The calculations have been made for all countries $c$ in 


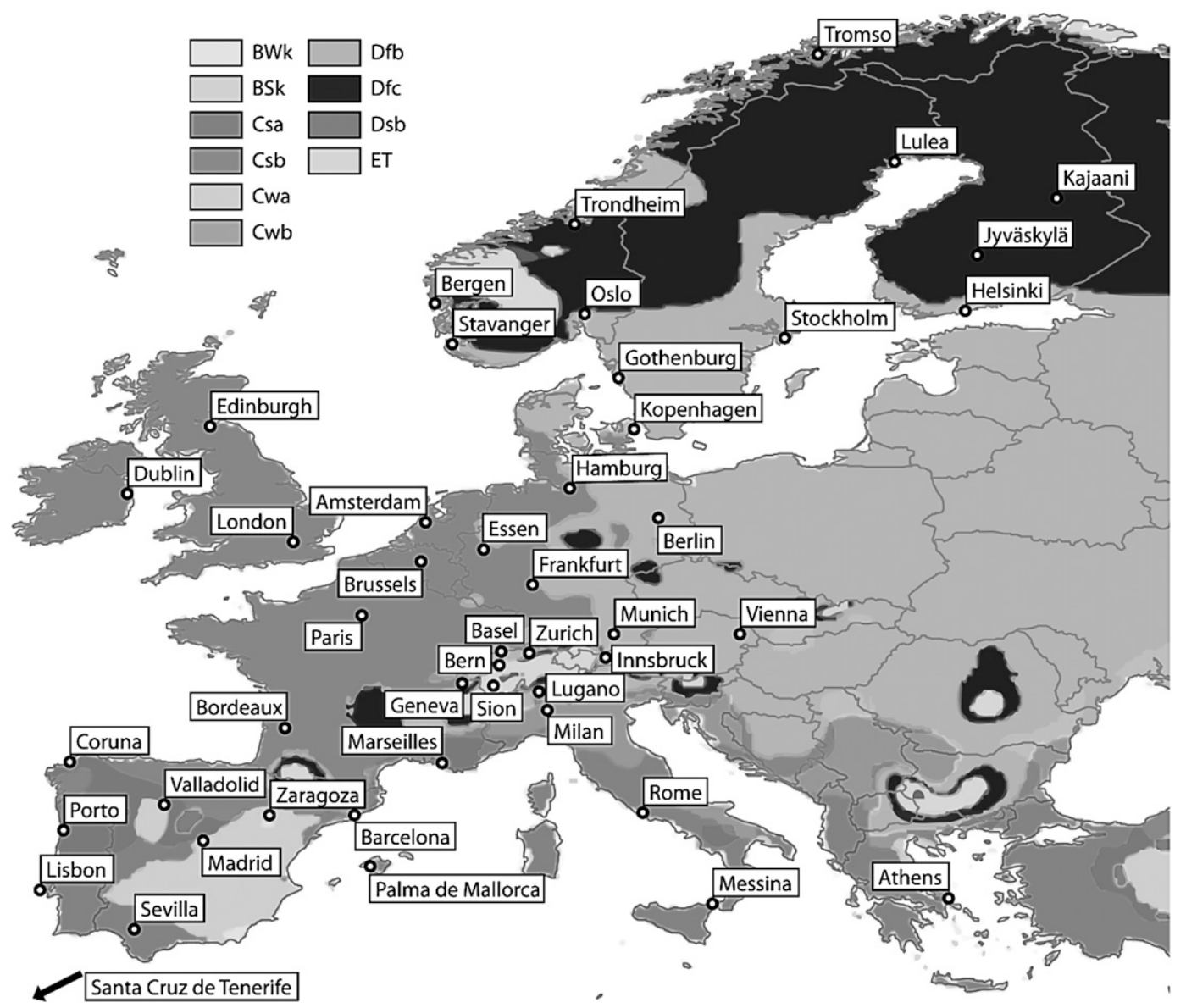

FIG. 3. Climate zones and selected climate stations in Europe. Explanations: BWk $=$ arid: cold desert; BSk $=$ arid: cold steppe; $\mathrm{Csa}=$ temperate: dry and hot summer; $\mathrm{Csb}=$ temperate: dry and warm summer; Cwa $=$ cold: dry winter and hot summer; $\mathrm{Cwb}=$ cold: dry winter and warm summer; Dfb = cold: without dry season and warm summer; Dfc $=$ cold: without dry season and cold summer; Dsb = cold: dry and warm summer; ET = polar: tundra. (For color map, see Fig. S3 in the supplementary material.) Source: Map from Peel et al. (2007); cities for the selected climate stations are added to the map by the author. (This figure is also available in color online at http://comparativepolitics. uni-greifswald.de.)

all the years $t$ from 1960 to 2005. Taking the example of Canada in the year 2000, Edmonton had 140.52 HDMs, Vancouver 56.76 HDMs, Winnipeg 158.4 HDMs, Toronto 95.88 HDMs, and Montreal 114.48 HDMs. In 2000, $9.83 \%$ of the Canadian population lived in Alberta, where Edmonton is the representative climate station; $13.04 \%$ of the population lived in British Columbia with Vancouver as the climate station; $7.07 \%$ of the population lived in Manitoba and Saskatchewan, with Winnipeg as the climate station; $43.97 \%$ of the population lived in New Brunswick, Nova Scotia, Ontario, and Prince Edward Island, with Toronto as the climate station; and Newfoundland and Québec had 26.08\% with Montreal as the station. Taking the proportional distribution of the population into account, the final HDM total for Canada in 2000 is 104.28 . The same calculation was conducted for all 21 OECD countries under investigation for every year from 1960 to 2005. Figure 5 shows the annual HDMs for all 21 OECD countries from 1960 to 2005.

The figure demonstrates considerable variation between the countries. The mean of the HDMs is 63.5 for all 21 OECD countries in the period from 1960 to 2005 . The minimum value is 5.24 (for Australia in 1988) and the maximum value is 156.96 (for Finland in 1985). Over time, there is a trend toward fewer HDMs in most but not all countries (e.g., Greece). The average of HDMs over all 21 OECD countries from 1960 to 1987 was always above $60 \mathrm{HDMs}$, except for 1961 (59.6). From 1988 to 2005 , less than $60 \mathrm{HDMs}$ was common in 13 of the 18 years. However, implying causal relationships is difficult from the data. Warmer winters may be one causal factor. Another reason may be that a large proportion of people moved from colder to warmer places within 

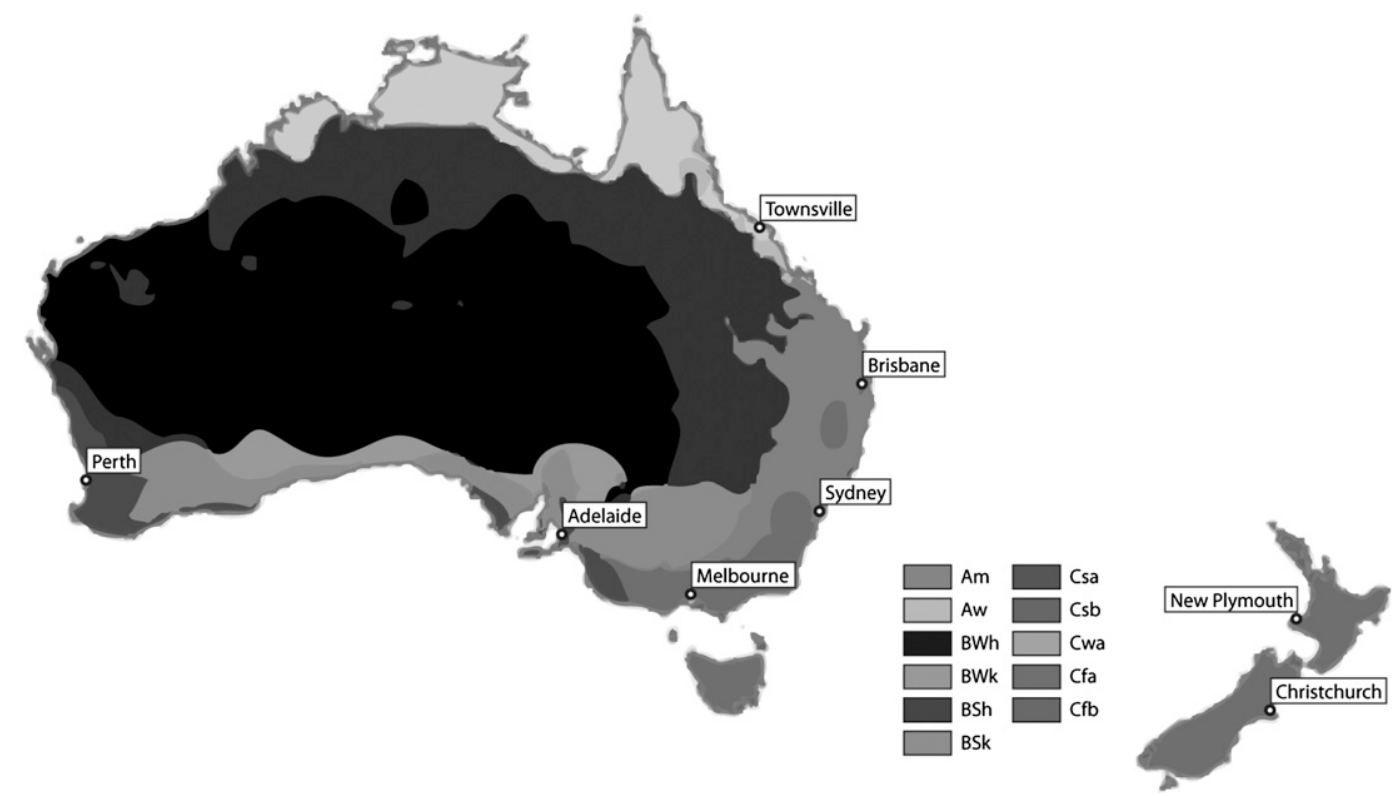

FIG. 4. Climate zones and selected climate stations in Australia and New Zealand. Explanations: Am = tropical: monsoon; $\mathrm{Aw}=$ tropical: savannah; $\mathrm{BWh}=$ arid: hot desert; $\mathrm{BWk}=$ arid: cold desert $\mathrm{BSh}=$ arid: hot steppe; $\mathrm{BSk}=$ arid: cold steppe; $\mathrm{Csa}=$ temperate: dry and hot summer; $\mathrm{Csb}=$ temperate: dry and warm summer; Cwa = temperate: dry winter and hot summer; $\mathrm{Cfa}=$ temperate: without dry season and hot summer; $\mathrm{Cfb}=$ temperate: without dry season and warm summer. (For color map, see Fig. S4 in the supplementary material.) Source: Map from Peel et al. (2007); cities for the selected climate stations are added to the map by the author. (This figure is also available in color online at http://comparativepolitics.uni-greifswald.de.)

a country. A case in point is the migration to Las Vegas in the United States, one of the fastest growing cities during this period. ${ }^{7}$ Similar migration trends are identifiable for California or the move from the north to the south in the Scandinavian countries. ${ }^{8}$

The standard deviation over all 21 countries from 1960 to 2005 is 34.01 HDMs. The countries with the highest variations of HDMs are Finland (11.71), Norway (11.19), and Sweden (10.43). All these countries are in relatively cold climates and annual changes of HDMs may have a significant effect on heating requirements and therefore atmospheric emissions. Countries with low changes in winter temperature are Australia (1.53), Greece (3.02), Portugal (3.06), and Spain (3.42). Table 1

\footnotetext{
${ }^{7}$ For the state of Nevada, where Las Vegas is located, the population has grown from 285000 in 1960 to about 2 million in 2000. This means that in $1960,0.16 \%$ of the U.S. population lived in Nevada whereas $0.71 \%$ did in 2000 .

${ }^{8}$ California had $8.8 \%$ of the U.S. population in 1960 and $12.04 \%$ in 2000. The East Coast states and the states aligned to the climate station of Chicago had half of the population in 1960. This figure went down to $38.8 \%$ in the year 2000. In Finland, the population in the south was $70 \%$ in 1960 and $77 \%$ in 2000 . In Sweden, the northern population went down from $12.4 \%$ to $9.9 \%$ and in Norway, the northern and central Norwegian population fell from $21.3 \%$ in 1960 to $18.9 \%$ in 2002 .
}

gives the basic statistical summary for the 21 OECD countries examined from 1960 to 2005.

To test the validity of the data, the HDMs are compared with the HDDs of the European Commission. A comparison with 14 western European countries over a time period from 1980 to 2005 was conducted. Over all the countries and years, Pearson's $r$ is 0.93 . This demonstrates a high correlation between the HDMs with the HDDs data of the European Commission. Concerning the individual countries, Pearson's $r$ varies from 0.83 in Ireland to 0.97 in Sweden. [The correlation for all $14 \mathrm{EU}$ countries is as follows: Austria 0.94; Belgium 0.97; Denmark 0.94; Finland 0.96; France 0.94; Germany 0.94; Greece 0.83; Ireland 0.83, Italy 0.85 ; Netherlands 0.95 ; Portugal 0.88; Spain 0.88; Sweden 0.97; and the United Kingdom 0.96. The correlation between the HDDs of the United States with a base temperature of $65^{\circ} \mathrm{F}$ and the HDMs with a base temperature of $15^{\circ} \mathrm{C}$ is 0.87 . The data for the United States were taken from http:// www7.ncdc.noaa.gov/CDO/CDODivisionalSelect.jsp (accessed June 2012).] Overall this is a very high correlation that supports the validity of the HDMs for the time period from 1960 to 2005. With this country and time coverage the dataset in this study is unique. (The dataset can be downloaded from www.comparativepolitics. uni-greifswald.de). 

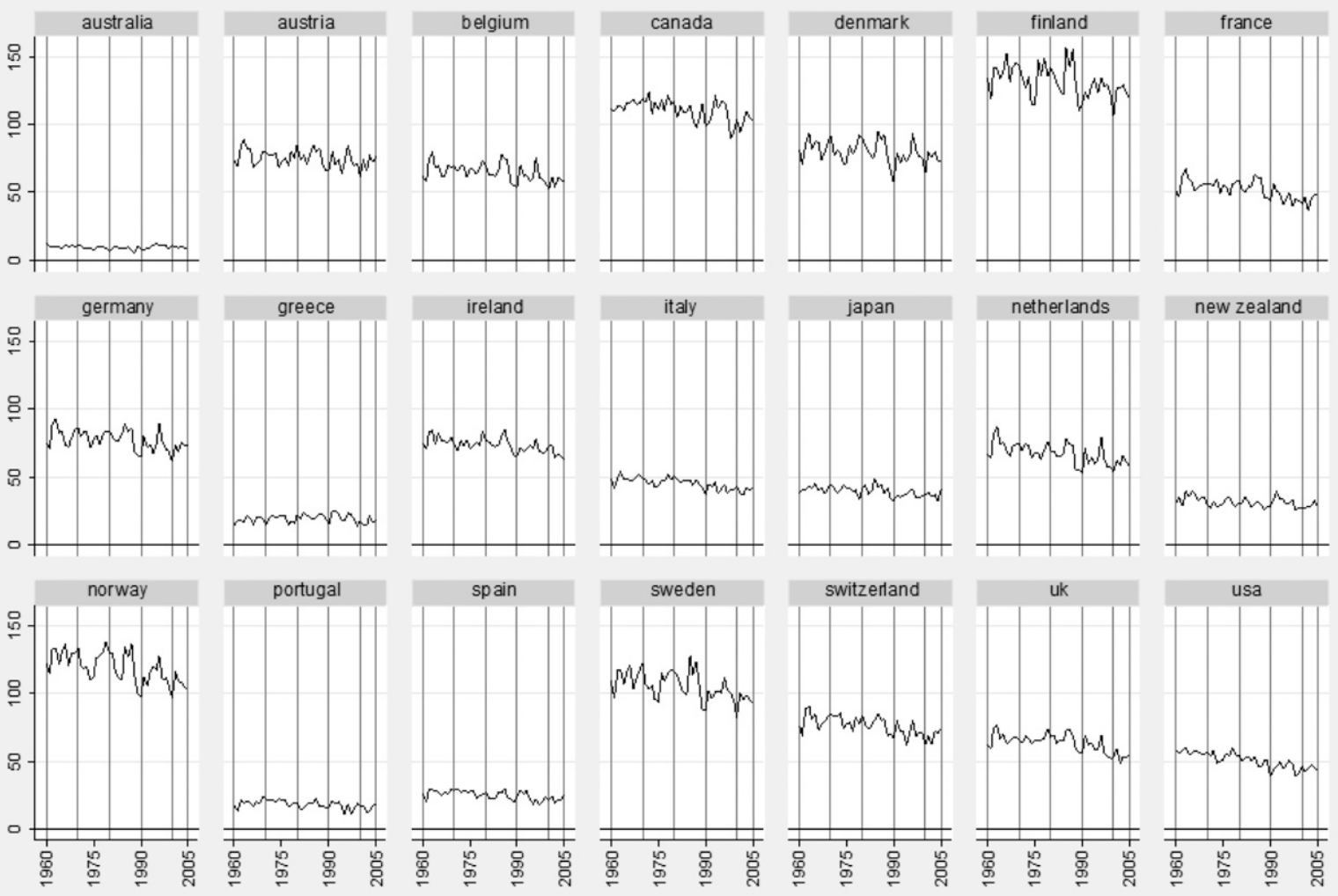

FIG. 5. Annual heating degree months in 21 OECD countries from 1960 to 2005.

\section{The impact of climate on atmospheric emissions}

The next step is to conduct regression analyses of the impact of climate on atmospheric emissions. Four atmospheric pollutants were included in this analysis: $\mathrm{SO}_{\mathrm{x}}, \mathrm{CO}, \mathrm{NO}_{\mathrm{x}}$, and $\mathrm{CO}_{2}$. [The data have been taken from the OECD Environmental Data Compendium (various years). The long-term $\mathrm{SO}_{\mathrm{x}}$ data were added from Stern's webpage (http://www.sterndavidi.com/datasite. html, accessed April 2010) and for $\mathrm{CO}_{2}$ emissions International Energy Agency (IEA) data were used (IEA 2010).] For $\mathrm{SO}_{\mathrm{x}}, \mathrm{CO}$, and $\mathrm{NO}_{\mathrm{x}}$ the emissions are measured in kilograms per capita, and for the $\mathrm{CO}_{2}$ emissions, in tons per capita. All of the selected atmospheric emissions are relevant for highly industrialized countries and all contribute to climate change. ${ }^{9}$

Highly industrialized countries have been very successful in reducing $\mathrm{SO}_{\mathrm{x}}$ emissions. From 1980 to 2005, $\mathrm{SO}_{\mathrm{x}}$ emissions decreased about $66 \%$ on average for the

\footnotetext{
${ }^{9}$ The gases $\mathrm{CO}, \mathrm{NO}_{\mathrm{x}}$, and $\mathrm{CO}_{2}$ contribute to global warming; however, $\mathrm{SO}_{\mathrm{x}}$ has the opposite effect since $\mathrm{SO}_{2}$ forms sulfate aerosols that reflect sun radiation back to space, and it also affects cloud formation.
}

21 OECD countries, with only three countries unable to reduce their emissions. Combating $\mathrm{CO}$ emissions was also substantial during this period, with a reduction of $51 \%$ overall, with 19 of 21 OECD countries successfully reducing $\mathrm{CO}$ emissions from 1980 to 2005. The reduction of $\mathrm{NO}_{\mathrm{x}}$ emissions was also noticeable, but on a more modest scale (reduction of $22 \%$ ). Six of the 21 OECD countries did not reduce their $\mathrm{NO}_{\mathrm{x}}$ emissions from 1980 to 2005. Finally, $\mathrm{CO}_{2}$ emissions are the least successful case in this study. Despite international commitments and pervasive political rhetoric arguing for the reduction of $\mathrm{CO}_{2}$ emissions, they increased by $5 \%$ from 1980 to 2005 in the 21 OECD countries. Only 10 of 21 OECD countries actually improved their emission rates of $\mathrm{CO}_{2}$ during this period.

As hypothesized above, climate should be a significant explanatory factor for atmospheric emissions when political action combating emissions effectively is not present. In reference to the four atmospheric pollutants described above, climate should have a significant explanatory value for $\mathrm{CO}_{2}$ emissions. The same may be true for $\mathrm{NO}_{\mathrm{x}}$ because emission reduction is moderate. For $\mathrm{CO}$ and above all $\mathrm{SO}_{\mathrm{x}}$ emissions, climate should have no significant effect. 
TABLE 1. Basic statistics of heating degrees months in 21 OECD countries from 1960 to 2005.

\begin{tabular}{lrrrr}
\hline \multicolumn{1}{c}{ Country } & Mean & Minimum & Maximum & $\begin{array}{r}\text { Standard } \\
\text { deviation }\end{array}$ \\
\hline Australia & 9.58 & 5.24 & 12.88 & 1.53 \\
Austria & 75.13 & 61.59 & 89.19 & 6.24 \\
Belgium & 64.79 & 52.60 & 80.10 & 6.76 \\
Canada & 110.54 & 89.66 & 123.91 & 7.68 \\
Denmark & 79.90 & 57.60 & 94.80 & 8.31 \\
Finland & 131.95 & 106.50 & 156.96 & 11.71 \\
France & 52.00 & 36.19 & 67.26 & 6.84 \\
Germany & 77.23 & 61.35 & 92.84 & 7.32 \\
Greece & 19.12 & 13.70 & 25.30 & 3.02 \\
Ireland & 73.40 & 62.30 & 85.30 & 5.44 \\
Italy & 45.02 & 36.80 & 53.28 & 4.21 \\
Japan & 39.31 & 32.08 & 49.39 & 3.74 \\
Netherlands & 67.04 & 52.20 & 87.20 & 7.84 \\
New Zealand & 31.20 & 24.81 & 39.65 & 3.76 \\
Norway & 118.91 & 96.78 & 137.51 & 11.19 \\
Portugal & 17.99 & 10.72 & 23.70 & 3.06 \\
Spain & 24.79 & 17.31 & 30.49 & 3.42 \\
Sweden & 105.49 & 82.03 & 127.67 & 10.43 \\
Switzerland & 76.13 & 61.82 & 90.82 & 6.97 \\
United Kingdom & 63.39 & 47.68 & 76.85 & 6.71 \\
United States & 50.72 & 38.67 & 60.32 & 5.67 \\
All countries & 63.51 & 5.24 & 156.96 & 34.01 \\
\hline & & & & \\
\hline
\end{tabular}

The regression models include some important control variables that refer to structural, technological, economic, and political aspects. Structural variables are related to the size of production sectors that may have a significant impact on atmospheric emissions. These sectors are mining, construction, and manufacturing, measured as percentage of persons employed in these sectors as a share of total employment. The service sector is often said to be more environmentally benign, but it is also possible that the high degree of consumption and resource-intensive activities (tourism, sports and other leisure activities, etc.) may be associated with environmental degradation (Panayotou 1993). [Data are from the OECD Structural Analysis (STAN) Database (http://www.oecd.org/industry/industryandglobalisation/ stanstructuralanalysisdatabase.htm), accessed December 2009.]

Technological progress may have a positive effect on atmospheric emissions. In this study, two major technologies are considered that have to do with energy production. One is nuclear energy, which reduces emissions levels substantially when replacing power stations running on fossil fuels. However, renewable energy technologies with low emissions such as solar and wind power have been developed recently and are contributing an increasing share of energy production in some countries. The shares of these energy technologies have been included as variables in the regression models.
The relationship between economic performance and atmospheric emissions is subject to considerable debate with several competing hypotheses about the causal effect of the economy on environmental performance (Jänicke et al. 1997). The most popular hypothesis begins from the assumption that economic performance causes environmental problems and increasing economic performance exacerbates environmental degradation (prosperity pollution hypothesis). In contrast, some have argued that there is not only a decoupling of economic growth and pollution, but that economic prosperity may lead to a cleaner environment (prosperity cleaning-up hypothesis) (Lomborg 1998). As Beckerman (1992, p. 491) claims: “... in the end the best - and probably the only-way to attain a decent environment in most countries is to become rich." In this study, the gross domestic product (GDP) per capita is included in the regression model. ${ }^{10}$

Finally, international treaties have been included as control variables for political action. For $\mathrm{SO}_{\mathrm{x}}$ and $\mathrm{NO}_{\mathrm{x}}$ the protocols and amendments for the treaty of LongRange Transboundary Air Pollution (LRTAP) has been included. For each country, the year of membership of the 1979, 1985, and $1994 \mathrm{SO}_{\mathrm{x}}$ treaties and the 1988, 1993, 1994 , and $1996 \mathrm{NO}_{\mathrm{x}}$ treaties was coded. For $\mathrm{CO}_{2}$ emissions, membership in the United Nations Framework Convention on Climate Change and the Protocol to the United Nations Framework Convention on Climate Change (Kyoto Protocol) was included. [The data are taken from Mitchell's website "The International Environmental Agreement's (IEA's) database" (http:// pages.uoregon.edu/rmitchel/; accessed June 2012) and the EcoLex database (www.ecolex.org; accessed April 2010).]

The data analysis was conducted in the standard tradition of time series-cross-sectional regression with panel-corrected standard errors (PCSE) and a firstorder autoregression correction (Beck and Katz 1995). Fixed effects and period dummies are included in the models in order to control for unspecified country and period effects, making the models relatively saturated. ${ }^{11}$ Table 2 shows the descriptive statistics of all variables included in the models, Table 3 shows the results.

For $\mathrm{SO}_{\mathrm{x}}$ and $\mathrm{CO}_{2}$ emissions, it is possible to conduct an analysis from 1960 to 2005 (models 1 and 8). For CO

\footnotetext{
${ }^{10}$ The data are taken from OECD. The GDP per capita has been divided by 1.000 to create coefficients with fewer zeros.

${ }^{11}$ The regression models have also been run without fixed effects and period effects as well as first difference models (changes from one year to the next). Concerning the HDM index the results are similar in respect to the significance although some control variables change their impact on atmospheric emissions.
} 
TABLE 2. Descriptive statistics for the variables used in the regression models.

\begin{tabular}{|c|c|c|c|c|c|c|}
\hline & Years covered & Observations & Mean & Std dev & Min & Max \\
\hline $\mathrm{SO}_{\mathrm{x}}$ emissions (kg per capita) & 1960-2005 & 966 & 51.49 & 47.30 & 2.24 & 315.90 \\
\hline $\mathrm{SO}_{\mathrm{x}}$ emissions (kg per capita) & 1980-2005 & 546 & 36.79 & 31.93 & 2.24 & 189.40 \\
\hline CO emissions (kg per capita) & 1980-2005 & 546 & 15.88 & 12.64 & 2.35 & 75.52 \\
\hline $\mathrm{NO}_{\mathrm{x}}$ emissions (kg per capita) & 1980-2005 & 546 & 39.69 & 19.28 & 11.13 & 95.89 \\
\hline $\mathrm{CO}_{2}$ emissions (tons per capita) & 1960-2005 & 966 & 8.78 & 4.16 & 0.66 & 22.19 \\
\hline $\mathrm{CO}_{2}$ emissions (tons per capita) & 1980-2005 & 546 & 9.40 & 3.85 & 2.44 & 20.50 \\
\hline HDMs & 1960-2005 & 966 & 63.51 & 34.01 & 5.24 & 156.96 \\
\hline HDMs & 1980-2005 & 546 & 61.31 & 33.10 & 5.24 & 156.96 \\
\hline Renewable energy & 1960-2005 & 966 & 0.06 & 0.23 & 0 & 2.95 \\
\hline Renewable energy & 1980-2005 & 546 & 0.11 & 0.29 & 0 & 2.95 \\
\hline Nuclear energy & 1960-2005 & 966 & 5.59 & 9.48 & 0 & 42.68 \\
\hline Nuclear energy & 1980-2005 & 546 & 9.10 & 11.26 & 0 & 42.68 \\
\hline GDP per capita/1.000 & 1960-2005 & 966 & 18.83 & 6.53 & 3.78 & 39.06 \\
\hline GDP per capita/1.000 & 1980-2005 & 546 & 22.79 & 5.15 & 10.34 & 39.06 \\
\hline Mining sector & 1980-2005 & 546 & 0.49 & 0.37 & 0.074 & 1.62 \\
\hline Construction sector & 1980-2005 & 546 & 7.10 & 1.54 & 4.14 & 12.64 \\
\hline Manufacturing sector & 1980-2005 & 546 & 18.60 & 4.02 & 10.33 & 31.26 \\
\hline Service sector & 1980-2005 & 546 & 65.63 & 8.453 & 39.21 & 81.21 \\
\hline International $\mathrm{SO}_{\mathrm{x}}$ treaties & $1960-2005$ & 966 & 0.84 & 1.06 & 0 & 3 \\
\hline International $\mathrm{SO}_{\mathrm{x}}$ treaties & 1980-2005 & 546 & 1.48 & 1.02 & 0 & 3 \\
\hline International $\mathrm{NO}_{\mathrm{x}}$ treaties & 1960-2005 & 966 & 0.74 & 1.47 & 0 & 4 \\
\hline International $\mathrm{NO}_{\mathrm{x}}$ treaties & 1980-2005 & 546 & 1.32 & 1.77 & 0 & 4 \\
\hline International $\mathrm{CO}_{2}$ treaties & 1960-2005 & 966 & 0.28 & 0.49 & 0 & 2 \\
\hline International $\mathrm{CO}_{2}$ treaties & 1980-2005 & 546 & 0.49 & 0.57 & 0 & 2 \\
\hline
\end{tabular}

and $\mathrm{NO}_{\mathrm{x}}$, as well as for the structural variables, data are only available from 1980 to 2005 . The results show that the hypothesis of this article is confirmed. HDMs have no impact on atmospheric emissions of pollutants that have improved substantially $\left(\mathrm{SO}_{\mathrm{x}}\right.$ and $\left.\mathrm{CO}\right)$. For $\mathrm{NO}_{\mathrm{x}}$, the pollutant with moderate reduction in emissions, HDMs are significant on the 0.05 level, suggesting that a $1^{\circ}$ change of HDM leads to a 70 -g increase in per capita $\mathrm{NO}_{\mathrm{x}}$ emissions. In other words, the average difference in HDMs between New Zealand and Finland shows that Finland would have seven kilograms per capita less $\mathrm{NO}_{\mathrm{x}}$ emissions if Finland had the climate conditions of New Zealand. This is around $14 \%$ of Finland's mean $\mathrm{NO}_{\mathrm{x}}$ emissions or $17.5 \%$ over the mean of $\mathrm{NO}_{\mathrm{x}}$ emissions for all 21 OECD countries in this study. For $\mathrm{CO}_{2}$ emissions, HDMs are significant at the 0.001 level, suggesting that a $1{ }^{\circ} \mathrm{C}$ increase in HDM results in a 0.03 tons increase of $\mathrm{CO}_{2}$ emissions. The difference of the HDMs between Australia and Canada, for example, leads to a three tons per capita difference of $\mathrm{CO}_{2}$ emissions, which is onethird of the average $\mathrm{CO}_{2}$ emissions for the selected 21 OECD countries.

These results hold when controlled for other variables that have a significant effect on atmospheric emissions. The structural variables are all significant in that polluting production sectors have a statistically positive (increase of emissions) effect. Not surprisingly, the mining sector has a very strong effect on $\mathrm{SO}_{\mathrm{x}}$ emissions.
However, in contrast to the assumption that countries with a large service sector are cleaner, the results show that the size of the service sector is actually associated with higher atmospheric emissions. Technological innovations such as nuclear energy and renewable energy have the predicted effect. In particular, the use of nuclear energy reduces atmospheric emissions. The significance of renewable energy is less clear. However, the reason may be that these technologies are rather new, forming relatively small percentages of the total energy output, suggesting that their impact may become more obvious in the future if implemented more rigorously.

The impact of GDP is interesting. If atmospheric emissions have been combated successfully, then GDP has a negative coefficient, suggesting that rich countries are more successful than poorer states. In contrast, atmospheric emissions that are less successfully reduced show a positive relation with GDP, meaning that GDP does not clearly impact but probably only reinforces preexisting trends.

Finally, international treaties for the reduction of $\mathrm{SO}_{\mathrm{x}}$, $\mathrm{NO}_{\mathrm{x}}$, and $\mathrm{CO}_{2}$ emissions actually have a highly significant effect on the reduction of $\mathrm{SO}_{\mathrm{x}}$ and $\mathrm{NO}_{\mathrm{x}}$ emissions but a much less significant effect on $\mathrm{CO}_{2}$ emissions. For instance, one international treaty concerning $\mathrm{SO}_{\mathrm{x}}$ emissions reduces per capita $\mathrm{SO}_{\mathrm{x}}$ emissions by five kilograms per capita, which is $13 \%$ of the mean $\mathrm{SO}_{\mathrm{x}}$ emissions in the period from 1980 to 2005. In the same period, an international treaty concerning $\mathrm{CO}_{2}$ 


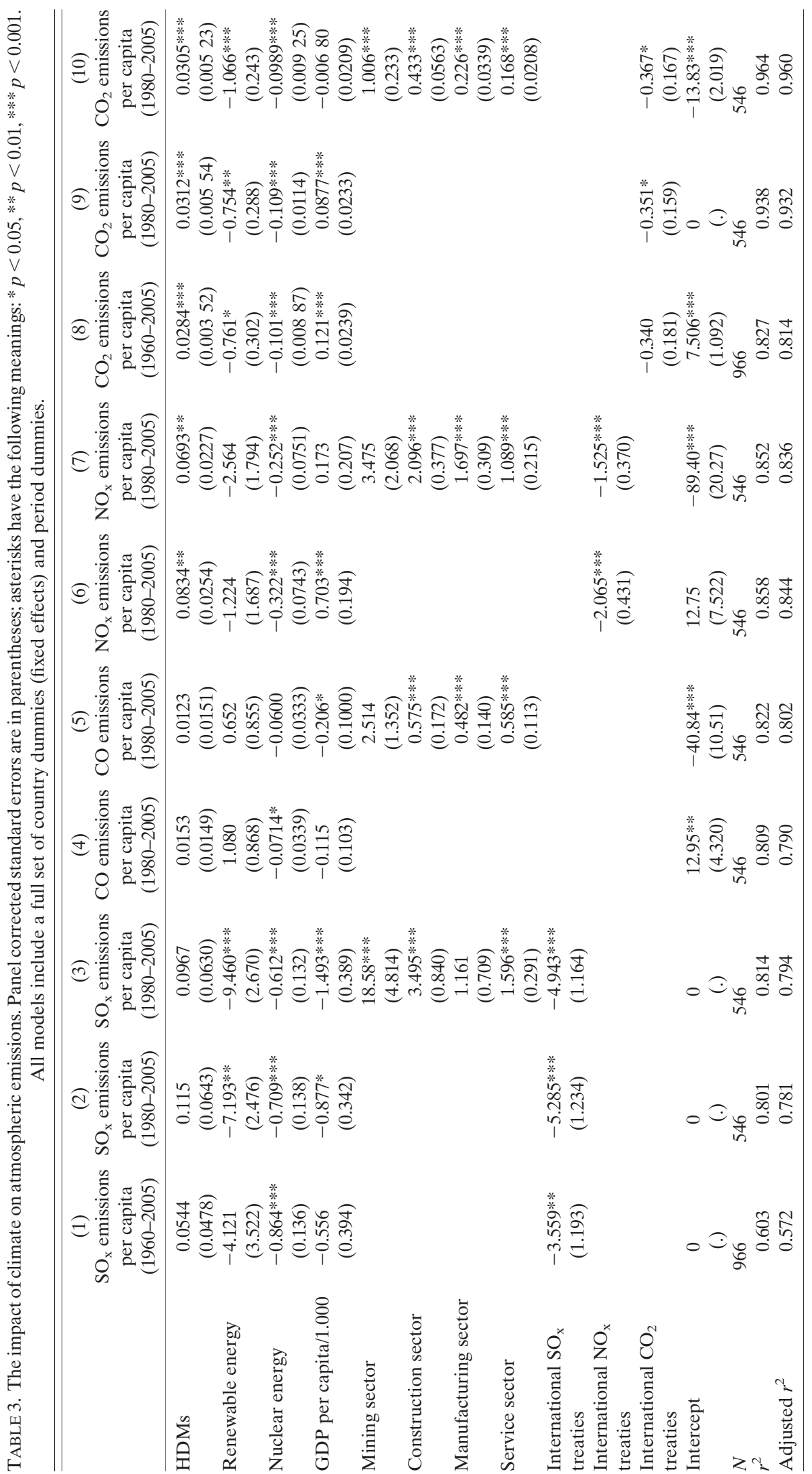


emissions has an effect of 0.35 tons per capita, which is just around $4 \%$ of the average $\mathrm{CO}_{2}$ emissions.

Standardized coefficients, ${ }^{12}$ which make it possible to compare the relative impact of each variable in each model, show that, for $\mathrm{SO}_{\mathrm{x}}$, nuclear energy and international treaties are the variables with the strongest impact. For $\mathrm{CO}$ and $\mathrm{NO}_{\mathrm{x}}$ emissions, it is the impact of the manufacturing and service sectors. In addition, for $\mathrm{NO}_{\mathrm{x}}$ emissions, the use of nuclear energy and international treaties, followed by climate, has a strong effect. For $\mathrm{CO}_{2}$ emissions, the size of the service sector has the largest effect, followed by the use of nuclear energy and climate-both with a similar impact. These results confirm the overall hypothesis that climate and weather conditions have a significant effect on atmospheric emissions when political action is less successful.

\section{Conclusions}

Climate is an important variable for the explanation of atmospheric emissions which, in turn, contribute to climate change. Therefore, an index with annual and country-specific temperature data has been developed that accounts for the concentration of the populated regions in a country. This index is expressed as HDMs, which are the annual monthly degrees below the level to which heating is necessary.

In this article, a detailed account has been given how to construct an index of HDMs that can be related to available data. Furthermore, the article also provides a brief illustration of the importance of such an index for the empirical analysis of atmospheric emissions. These results demonstrate that climate and temperature have significant effects on atmospheric emissions. This is particularly true when regarding particular atmospheric emissions such as $\mathrm{CO}_{2}$ that have not been successfully combated through policy. When atmospheric emissions are reduced, factors other than HDMs are important, implying that improved atmospheric emissions are significantly altered by human and political actions thus rendering HDMs insignificant.

\footnotetext{
${ }^{12}$ Analysis is not shown here but is available on request by the author.
}

The primary goal of this article was to develop an index of annual climate data that is representative for 21 OECD countries. On the one hand, this unique dataset harmonizes similar but not comparable datasets available for some countries and for a limited time period. On the other hand, for some countries, no equivalent data existed before and therefore this index is novel for these countries. Consequently, the HDM index developed in this article enables researchers to apply this index for most highly industrialized democratic states over a time period from 1960 to 2005.

Climate and weather conditions might be important not only for atmospheric emissions. Other pollutants may also dependent on HDMs. Furthermore, besides cold winters, hot summers may also be important. Hot summers increase energy production by the use of air conditioners or the increase of pollution concentration in rivers and lakes because of low water levels. For such an analysis, a similar index of cooling degree months (CDMs) has been constructed (D. Jahn 2012, unpublished manuscript). Including HDMs and CDMs will increase the precision of analyses dealing with environmental problems. This is needed in order to explain pollution levels and their trends in modern societies. $^{13}$

Acknowledgments. The results obtained for this paper stem from the research project "Environmental Pollution as a Global Phenomenon" sponsored by the German Research Foundation (DFG). I wish to thank Christoph Oberst, Lena Masch, Katja Staack, Kati Kuitto, and Thomas Behm for help with the data collection, as well as Douglas Voigt for suggestions and editing. The paper was presented at the 8th International Summer Academy on Energy and the Environment in Guildford, UK, June 2329, 2011 where I received numerous helpful comments from fellow participants. I also thank Roger Karapin at Hunter College and the CUNY Graduate Center who gave many helpful suggestions. Finally, I thank the four anonymous reviewers for very thoughtful and detailed comments and suggestions.

\footnotetext{
${ }^{13}$ Of course HDMs and CDMs are also important for the analysis of developing countries. However, constructing indices for those countries is a challenging task for future research.
} 


\section{APPENDIX}

\section{Climate Stations}

Tables A1 and A2 are presented below.

TABLE A1. Climate stations and aligned regions of 20 OECD countries.

\begin{tabular}{|c|c|c|}
\hline Country & Climate stations & Regions \\
\hline \multirow[t]{6}{*}{ Australia } & Townsville & Northern Territory \\
\hline & Brisbane & Queensland \\
\hline & Adelaide & Southern Australia \\
\hline & Perth & Western Australia \\
\hline & Sydney & New South Wales \\
\hline & Melbourne & Victoria, Tasmania \\
\hline \multirow[t]{2}{*}{ Austria } & Vienna & Burgenland, Niederösterreich, Oberösterreich, Steiermark, Wien \\
\hline & Innsbruck & Kärnten, Tirol, Vorarlberg, Salzburg \\
\hline Belgium & Brussels $(=$ Uccle $)$ & Whole country \\
\hline \multirow[t]{5}{*}{ Canada } & Edmonton & Alberta \\
\hline & Vancouver & British Columbia \\
\hline & Winnipeg & Manitoba, Saskatchewan \\
\hline & Toronto & New Brunswick, Nova Scotia, Ontario, Prince Edward Island \\
\hline & Montreal & Newfoundland, Québec \\
\hline Denmark & Copenhagen & Whole country \\
\hline \multirow{3}{*}{ Finland } & Helsinki & Etelä-Suomi, Länsi-Suomi, Ahvenanmaa \\
\hline & Jyväskylä & Itä-Suomi \\
\hline & Kajaani & Oulu, Lappi \\
\hline \multirow[t]{3}{*}{ France } & Paris & $\begin{array}{l}\text { Alsace, Auvergne, Bourgogne, Centre, Champagne-Ardenne, Franche-Comté, } \\
\text { Île-de-France, Limousin, Lorraine, Nord-Pas-de-Calais, Basse-Normandie, } \\
\text { Haute-Normandie, Picardie, Rhône-Alpes }\end{array}$ \\
\hline & Bordeaux & Aquitaine, Bretagne, Pays de la Loire, Midi-Pyrénées, Poitou-Charentes \\
\hline & Marseilles & Corse, Languedoc-Roussillon, Provence-Alpes-Côte d'Azur \\
\hline \multirow[t]{5}{*}{ Germany } & Hamburg & $\begin{array}{l}\text { Bremen, Hamburg, Mecklenburg-Vorpommern, Niedersachsen, Sachsen-Anhalt, } \\
\text { Schleswig-Holstein }\end{array}$ \\
\hline & Berlin & Berlin, Brandenburg, Sachsen, Thüringen \\
\hline & Essen & Nordrhein-Westfalen \\
\hline & Frankfurt & Hessen, Rheinland-Pfalz, Saarland \\
\hline & Munich & Baden-Württemberg, Bayern \\
\hline Greece & Athens & Whole country \\
\hline Ireland & Dublin & Whole country \\
\hline \multirow[t]{3}{*}{ Italy } & Milan & $\begin{array}{l}\text { Emilia-Romagna, Friuli-Venezia Giulia, Liguria, Lombardia, Piemonte, Toscana, } \\
\text { Trentino-Alto Adige, Umbria, Valle d'Aosta, Veneto }\end{array}$ \\
\hline & Rome & Abruzzo, Campania, Lazio, Marche, Molise, Puglia, Sardegna \\
\hline & Messina & Basilicata, Calabria, Sicilia \\
\hline \multirow[t]{7}{*}{ Japan } & Sapporo & Hokkaidô \\
\hline & Tokyo & $\begin{array}{l}\text { Chiba, Fukushima, Ibaraki, Iwate, Kanagawa, Miyagi, Saitama, Tochigi, Tôkyô, } \\
\text { Aichi, Shizuoka, Yamanashi }\end{array}$ \\
\hline & Fukuoka & $\begin{array}{l}\text { Fukuoka, Kagawa, Kagoshima, Kôchi, Kumamoto, Miyazaki, Nagasaki, Okinawa, } \\
\text { Saga, Tokushima }\end{array}$ \\
\hline & Osaka & $\begin{array}{l}\text { Ehime, Hiroshima, Hyôgo, Kyôto, Mie, Nara, Ôita, Ôsaka, Shimane, Tottori, } \\
\text { Wakayama, Yamaguchi }\end{array}$ \\
\hline & Matsumoto & Gumma, Nagano, Gifu, Okayama \\
\hline & Wajima & Niigata, Fukui, Ishikawa, Shiga, Toyama, \\
\hline & Akita & Akita, Aomori, Yamagata \\
\hline Netherlands & Amsterdam (=De Bilt) & Whole country \\
\hline \multirow[t]{2}{*}{ New Zealand } & New Plymouth & North Island \\
\hline & Christchurch & South Island \\
\hline \multirow[t]{5}{*}{ Norway } & Troms $\varnothing$ & Finnmark, Troms \\
\hline & Trondheim & Nordland, Nord-Trøndelag, Sør-Trøndelag \\
\hline & Bergen & Hordaland, Møre og Romsdal, Sogn og Fjordane \\
\hline & Oslo & $\begin{array}{l}\text { Akershus, Aust-Agder, Buskerud, Hedmark, Oppland, Østfold, Oslo, Telemark, } \\
\text { Vestfold }\end{array}$ \\
\hline & Stavanger & Rogaland, Vest-Agder \\
\hline
\end{tabular}


TABLE A1. (Continued)

\begin{tabular}{|c|c|c|}
\hline Country & Climate stations & Regions \\
\hline \multirow[t]{2}{*}{ Portugal* } & Lisbon & Lisbon, Leiria, Santarém, Setúbal, Beja, Faro, Évora, Portoalegre \\
\hline & Porto & $\begin{array}{l}\text { Castelo Branco, Guarda, Coimbra, Aveiro, Viseu, Bragança, Vila Real, Porto, } \\
\text { Braga, Viana do Castelo }\end{array}$ \\
\hline \multirow[t]{8}{*}{ Spain } & La Coruna & Asturias, Cantabria, Galicia, Navarra, País Vasco \\
\hline & Barcelona & Catalunya, Murcia, València \\
\hline & Madrid & Castilla-La Mancha, Madrid, Rioja (La Rioja) \\
\hline & Sevilla & Andalucía, Extremadura \\
\hline & Palma de Mallorca & Balears (Illes Balears) \\
\hline & Valladolid & Castilla y Léon, \\
\hline & Santa Cruz de Tenerife & Canarian Islands \\
\hline & Zaragoza & Aragón \\
\hline \multirow[t]{4}{*}{ Sweden } & Luleå & Jämtland, Norrbotten, Västerbotten, Västernorrland \\
\hline & Stockholm & $\begin{array}{l}\text { Dalarna, Gävleborg, Kristianstad, Örebro, Östergötland, Södermanland, } \\
\text { Stockholm [City], Stockholm, Uppsala, Värmland, Västmanland }\end{array}$ \\
\hline & Gothenburg & Älvsborg, Göteborg och Bohus, Skaraborg, Västra Götaland \\
\hline & $\begin{array}{l}\text { South Sweden } \\
\text { (=Copenhagen) }\end{array}$ & Blekinge, Gotland, Halland, Jönköping, Kalmar, Kronoberg, Malmöhus, Skåne \\
\hline \multirow[t]{6}{*}{ Switzerland } & Basel & Solothurn, Basel-Stadt, Basel-Landschaft, Schaffhausen, Aargau, Jura \\
\hline & Zurich & $\begin{array}{l}\text { Zürich, Luzern, Uri, Schwyz, Nidwalden, Glarus, Zug, Appenzell Ausser Rhoden, } \\
\text { Appenzell Inner Rhoden, Sankt Gallen, Graubünden, Thurgau }\end{array}$ \\
\hline & Geneva & Vaud, Neuchâtel, Genève \\
\hline & Lugano & Ticino \\
\hline & Bern & Bern, Obwalden, Fribourg \\
\hline & Sion & Valais \\
\hline \multirow[t]{3}{*}{ United Kingdom } & London & England \\
\hline & Edinburgh & Scotland \\
\hline & Dublin & Wales and Northern Ireland \\
\hline
\end{tabular}

* For Portugal, Madeira and the Azores are excluded. The percentage has been calculated on the districts mentioned in the table.

TABLE A2. Climate stations and states in the United States.

\begin{tabular}{ll}
\hline \multicolumn{1}{c}{ Climate station } & \\
\hline Anchorage & Alaska \\
Miami & Florida \\
Atlanta & Alabama, Delaware, District of Columbia, Georgia, Louisiana, North Carolina, South Carolina, \\
& Tennessee, Virginia \\
New Orleans & Mississippi \\
Houston; San Antonio; Dallas & Texas $=(2 \times$ Houston, $2 \times$ Dallas, $1 \times$ San Antonio $) / 5$ \\
Dallas & Arkansas, Oklahoma \\
Phoenix & Arizona \\
San Diego* & South California \\
San Francisco* & North California \\
Las Vegas & Nevada \\
Denver & Colorado \\
New York & Connecticut, Maryland, New Jersey, New York, Pennsylvania \\
Boston & Maine, Massachusetts, New Hampshire, Rhode Island, Vermont \\
Chicago & Illinois, Indiana, Iowa, Michigan, Ohio, Wisconsin \\
Salt Lake City & Idaho, Nebraska, Utah, Wyoming \\
Minneapolis & Minnesota, Montana, North Dakota, South Dakota \\
Seattle & Oregon, Washington \\
Albuquerque & New Mexico \\
St. Louis & Kansas, Missouri, Kentucky, West Virginia \\
Honolulu & Hawaii \\
\hline
\end{tabular}

* California has been divided into Southern (Imperial, Kern, Los Angeles, Orange, Riverside, San Bernardino, San Diego, San Luis Obispo, Santa Barbara, Ventura) and northern (all other counties) California. 


\section{REFERENCES}

ASHRAE, 2004: ASHRAE Standard 55-2004: Thermal environmental conditions for human occupancy.

Barnett, T., 2005: Detecting and attributing external influences on the climate system: A review of recent advances. J. Climate, 18, 1291-1314.

Beck, N., and J. N. Katz, 1995: What to do (and not to do) with timeseries cross-section data. Amer. Polit. Sci. Rev., 89, 634-647.

Beckerman, W., 1992: Economic growth and the environment: Whose growth? Whose environment? World Dev., 20, 481-496.

Essenwanger, O. M., and H. E. Landsberg, 2001: General Climatology 1C. Vol. 1, Part 3, World Survey of Climatology, Elsevier Science, 126 pp.

European Commission, 2007: Panorama of Energy. Energy Statistics to Support EU Policies and Solutions. Office for Official Publications of the European Communities, $166 \mathrm{pp}$.

Fanger, P. O., 1973: Thermal Comfort. McGraw-Hill, 244 pp.

IEA, cited 2010: $\mathrm{CO}_{2}$ Emissions from Fuel Combustion. International Energy Agency. [Available online at http://www.iea org/co2highlights/co2highlights.pdf.]

Jahn, D., 1998: Environmental performance and policy regimes: Explaining variations in 18 OECD countries. Policy Sci., 31, 107-131.

Jänicke, M., H. Mönch, T. Ranneberg, and U. E. Simonis, 1989: Structural change and environmental impact. Intereconomics, 24, 24-35.

- M. Binder, and H. Mönch, 1997: 'Dirty industries': Patterns of change in industrial countries. Environ. Resour. Econ., 9, 467491.

Köppen, W. P., 1900: Versuch einer Klassifikation der Klimate vorzugsweise nach ihren Beziehungen zur Pflanzenwelt. Geogr. Z., 6, 593-611 and 657-659.

1918: Klassifikation der Klimate nach Temperatur, Niederschlag und Jahreslauf. Petermanns Geogr. Mitt., 64, 193-203 and 243-248. and R. Geiger, 1936: Handbuch der Klimatologie. Vol. 1. Gebrüder Borntraeger, $44 \mathrm{pp}$.

Kottek, M., J. Grieser, C. Beck, B. Rudolf, and F. Rubel, 2006: World map of the Köppen-Geiger climate classification updated. Meteor. Z., 15, 259-263.

Lahmeyer, J., cited 2006: Population statistics: Historical demography of all countries, their divisions and towns. [Available online at http://www.populstat.info.]

Li, Q., and R. Reuveny, 2009: Democracy and Economic Openness in an Interconnected System: Complex Transformations. Cambridge University Press, $350 \mathrm{pp}$.

Lohmann, U., R. Sausen, L. Bengtsson, U. Cubasch, J. Perlwitz, and E. Röckner, 1993: The Köppen climate classification as a diagnostic tool for general circulation models. Climate Res., 3, 177-193.

Lomborg, B., 1998: The Skeptical Environmentalist: Measuring the Real State of the World. Cambridge University Press, $515 \mathrm{pp}$.

Neumayer, E., 2003: Are left-wing party strength and corporatism good for the environment? Evidence from panel analysis of air pollution in OECD countries. Ecol. Econ., 45, 203220.

Orosa, J. A., 2009: Research on general thermal comfort models. Eur. J. Sci. Res., 27, 217-227.

Panayotou, T., 1993: Empirical tests and policy analysis of environmental degradation at different stages of economic development. Working Paper WP 238, Technology and Employment Programme, International Labour Office, 27 pp.

Peel, M. C., B. L. Finlayson, and T. A. McMahon, 2007: Updated world map of the Köppen Geiger climate classification. $H y$ drol. Earth Syst. Sci., 11, 1633-1644.

Sanderson, M., 1999: The classification of climates from Pythagoras to Koeppen. Bull. Amer. Meteor. Soc., 80, 669-673.

Scruggs, L., 2003: Sustaining Abundance: Environmental Performance in Industrial Democracies. Cambridge University Press, $268 \mathrm{pp}$. 